\title{
The Impact of Investment Decision and Funding on Financial Performance and Firm Value
}

\author{
Hadi Santoso* \\ Program Studi Manajemen, STIE Widya Dharma Pontianak, Indonesia
}

\begin{abstract}
Managers who are responsible for the management of companies are faced with two important decisions - investment and funding. The right investment decisions and choice of funding sources are important because they affect the company's financial performance. The selection of the types of assets to be invested and the right types of financing sources result in optimal returns for the company. It reflects good company performance and future prospects. In addition, optimal return is a good sign for investors. Companies that perform well experience increase in the value of their firm. This study examined the effect of investment decisions and the selection of appropriate sources of funds on the performance of the company and the consequent impact on the firm value. The study was conducted in two parts. The first part examined the effect of investment decisions on long-term assets with long-term funding on the rate of return and firm value. The second part examined the effect of investment decisions on the company's short-term assets and funding for financial performance and firm value. The case study used in this research is a consumer goods sub-sector company listed on the Indonesia Stock Exchange in the period 2010 to 2017. Path analysis is the data analysis tools that was used. The results of data analysis showed that the asset structure has an effect on financial performance and firm value. The capital structure affects the financial performance but does not affect the firm value of the company. Financial performance was measured by ROI.
\end{abstract}

JEL : 016

Keywords: investment, funding decisions, financial performance, firm value

\section{INTRODUCTION}

Firm value is the investor's expectation of the company which is measured by the company's stock price. It is the present value of all profits of future shareholders (Sartono, 2000:11). Martono \& Harjito (2003:13) reveal that for companies that have not gone public, the firm value can be gotten from the value of the company when it is sold. Djaja (2017:3) argues that investors expect the investment value of the company they invest in to rise or at least be equal to the compensation for the risk taken, when the time value of money is taken into consideration.

Firm value reflects the ability of the management of an organization to make investment decisions and financial planning (Ross, Westerfield, Jaffe, \& Jordan, 2015:11). The

\footnotetext{
*E-mail : hadi_goi@yahoo.co.id

Received : 01-02-2019, Accepted : 06-02-2019, Published : 29-08-2019

P-ISSN : 2087 - 9954, E-ISSN : 2550 - 0066. DOI : http://dx.doi.org/10.26418/jebik.v8i2.31153
} 
determination of whether the firm value of a company is high or low can be seen in the financial performance of such company which comes as a reflection of series of decisions taken by the management of the company. According to Harjito \& Martono (2013:4) management decisions are reflected in three main areas of financial management - investment decisions, funding decisions and asset management.

Investment decisions are the most important decisions because they relate directly to investment profitability (Riyanto, 2013:10). Harjito \& Martono (2013:5) state that a company's investment decisions are reflected in the types of assets the company invested in. This is mostly seen on the assets section of the financial statement of the company which shows what makes up current assets as well as the fixed assets. This is important because the composition of current assets and fixed assets forms the structure of the company's wealth (Riyanto, 2013:19).

Funding decisions have to do with the determination of funding sources needed to finance investments (Harjito \& Martono, 2013). There are two sources a company can explore to get funds - internal funding sources and external funding sources. Internal funds come from the company's operational results for example retained earnings. External funding sources are the funds generated from outside the company such as debt sources and the issuance of new shares. The balance that comes from the use of own capital with debt is known as the capital structure. In its implementation, companies must be able to find efficient funding sources. This happens when the company has an optimal capital structure that can minimize capital costs and maximize the firm value.

In this article, the researcher studies the effect of investment decisions and funding decisions on financial performance and firm value. The financial ratio data of the consumer goods industry sector for the last seven years shows that the average investment in fixed assets has only reached $32 \%$. The debt to total assets ratio is around $41 \%$, the average net profit margin is $9.5 \%, 27 \% \mathrm{ROI}$ and $5.3 \mathrm{PBV}$. This condition shows that opportunities for growth in this sector are still quite large. Therefore model testing uses industrial data on the consumer goods sector. The article is divided into five parts. The first part discusses the introduction, section two discusses literature review, section three discusses research methodology and data processing, section four discusses the results of research while the fifth section discusses conclusions and suggestions.

\section{LITERATURE REVIEW}

The purpose of financial management is to maximize the value of shares. Companies that have not sold their shares to the public are able to maximize the firm value through the maximization of owner's equity value Ross et al. (2015:11). According to Harjito \& Martono (2013:3) the value of a company has the possibility of showing the value of assets, such as shares, owned by such company. Harjito \& Martono (2013:3) also argue that the prosperity of the owner of a company is related to the company's ability to make profit. Companies that are able to get high profits and consistently distribute dividends to shareholders increases investor perceptions about them. These companies also have increasing stock price which consequently increases their firm value Harjito \& Martono (2013:3). The size of the dividend paid depends on the ability of management to manage the company resources to make profit. 
Firm value of a company can be measured from two different perspectives, internally from within the company and externally. Internally, it can be measured by using return on equity (Brigham \& Houston, 2006). Externally, it can be measured by using market to book value (Ross et al., 2015). Market to book value measures market expectations for company performance that is associated with the value of the company's shares book. According to Ross et al. (2015:54) when a company is said to have less than one market to book value, it means that the company fails to create value for shareholders. Brigham \& Gapenski (1997:55) reveal that companies that are successful in their management get very high recognition which is reflected in their excess stock market prices which are higher than the value of the book. The company's value reflects the company's management ability to achieve good performance.

Company performance reflects the results obtained by the company in utilizing the assets or equity held to get profit (Riyanto, 2013). A good company is a company that is efficient in using its assets or capital. Company performance evaluates management activities in managing corporate finances. Performance measurement is carried out to evaluate the effectiveness and efficiency of company management in managing investment and funding sources of the company (Martono \& Harjito, 2003). Assessment of the company's financial performance is conducted by analyzing the company's financial statements. From the financial statements submitted by the company, the company's ability to manage short-term and long-term funding sources, the ability of companies to utilize their assets effectively and efficiently, and the company's ability to create value can be analyzed (Ross et al., 2015).

\subsection{The effect of assets structure on financial performance}

The structure of assets owned by a company shows investment decisions made by the company's management. It can be seen on the asset section of the financial position report which shows the composition of current assets and fixed assets (Harjito \& Martono, 2013). Current assets represent the working capital of the company needed to carry out daily operational activities. Fixed assets are assets with an economic life of more than one year used in supporting the operating activities of a company. The accuracy of the decision made towards selecting the type of assets to invest in is very important because it relates to the costs that must be incurred by the company. The effectiveness of the use of the assets of a company is reflected in the company's high sales (Brigham \& Houston, 2006).

According to Harjito \& Martono (2013:5), if the selection of fixed asset type is right and its use is efficient, it will have a direct impact on the company's profitability. The higher the level of sales achieved by the company the higher the operating profit (Brigham \& Houston, 2006). Olatunji \& Adegbite, (2014) find that asset structure has a positive effect on operating activities in banking companies in Nigeria. Muritala (2012) and Mursalim, Hendragunawan, Alamzah, \& Sanusi (2015) also find that the asset structure has a positive effect on operating activities proxied by return on assets and return on equity. Vătavu (2015) find different results for Romanian companies. According to her research, companies in Romania were not efficient in the utilization of their assets. The hypothesis of ths argument is:

$\mathbf{H}_{1}$ : Asset structure has a positive effect on financial performance.

\subsection{Assets Structure Mediated by Financial Performance has A Effect on Firm Value}


From the description above, it can be concluded that the asset structure has a positive effect on operating activities. Investment in the right assets and efficient use of operating activities results in maximum company performance. In addition, positive company performance receives positive response from investors. Therefore, it can be deduced that proper utilization of the assets of a company has effects on the performance of the company as well as the perception of the investors about the firm value. The hypothesis of ths argument is:

$\mathbf{H}_{2}$ : Asset structure has a positive effect on firm value.

$\mathbf{H}_{3}$ : Asset structure mediated by financial performance has a positive effect on firm value.

\subsection{The Effect of Capital Structure on Financial Performance}

The capital structure shows the composition of corporate funding sources consisting of liabilities and equity (Harjito \& Martono, 2013). According to the pecking order theory, companies that consistently earn large profits tend to use small debt compared to their own capital. This happens because most of the operational costs have been covered by internal funding sources. Debt use is only to cover the lack of internal funding sources (Ross et al., 2015). Regarding the capital structure, there are several theories that have been put forward. According to Trade off theory, companies that use debt in their operations must bear the cost of capital in the form of loan interest but can obtain benefits in the form of tax savings (tax shield). Its savings will decrease when debt usage gets bigger (Myers, 2001). If the use of debt continues to be added, it can lead to companies experiencing financial distress in the form of bankruptcy costs and agency fees.

According to Myers (2001), optimal debt levels will be achieved when tax savings reach the maximum amount against the cost of financial difficulties. Harjito \& Martono (2013:10) argue that as long as the use of debt has not reached the optimal capital structure point, then any additional debt in operations will provide tax benefits. Increasing the debt ratio to the capital structure will increase profit. The increase in profit will be eroded by an increase in debt costs and agency costs (Ross et al., 2015:454). Various researches on the influence of capital structure on financial performance have been carried out. The study results of Boroujeni, Noroozi, Nadem, $\&$ Chadegani (2013) report that the increase in the company's debt ratio in Tehran had a positive effect on company performance as measured by return on assets. The same results were found by Chaganti \& Damanpour (1991) who find that capital structure has a positive effect on profitability. Mursalim et al. (2015) examined 22 companies on the Indonesia Stock Exchange and also submit that capital structure has a positive effect on profitability.

Different research results were shown by Salim \& Yadav (2012) towards companies in Malaysia. Their results show that short-term debt has a negative effect on profitability as measured by return on equity. While long-term debt negatively affects return on assets. Muritala (2012) find the same thing for Nigerian companies by showing that debt ratio negatively affect return on assets. In contrast, the research results of Salim \& Yadav (2012) \& Muritala (2012) show that the debt ratio conditions of the companies studied are large and that there is inefficient use of assets by these companies. Therefore, if a company incurs a debt burden, it would increase the cost of capital and reduce performance of corporate finance of such company. The hypotesis of the argument is: 
H4: Capital structure has a positive effect on financial performance.

\subsection{The Effects of Capital Structure on Firm Value}

Based on this explanation, it can be concluded that the capital structure has a positive effect on the company's financial performance and that investors respond well to this performance. Investors believe that the use of appropriate and effective funding sources is a signal that the company has good prospects and this will make investors invest in the company's shares. Therefore, the hypothesis of the argument is:

H5: Capital structure has a positive effect on firm value.

\subsection{Capital Structure Mediated by Financial Performance has An Effect on Firm Value}

Investors pay attention to the final results of a company's operating activities when they are planning to invest. Selection of right investment and manage funding sources by a company's management results in good financial performance. This is measured by maximum profitability achieved by the company (Riyanto, 2013:37). The financial statements issued by the company form the basis for the analysis carried out by investors in assessing company's performance (Riyanto, 2013:328). Investors react positively to the financial statements of well performing companies and that is the reason companies try to convey positive information to investors regarding the results achieved by them. This action is in accordance with the signaling theory (Brigham \& Gapenski, 1997). The reaction shown by investors through their investment in the company's shares will increase the firm value's shares. Chen (2002) study of 127 Dutch companies reveals that the coefficient of capital structure was positive but did not affect the firm value. Prasad, Bruton, \& Merikas (1997) examined the effect of capital structure on the firm value using data from 810 American companies and find that capital structure has influence on firm value.

H6: Capital structure mediated by financial performance has a positive effect on firm value.

\subsection{The Effect of Financial Performance on Firm Value}

Bhullar (2017) research shows the positive influence of company's profitability on the value of Indian fast-moving companies in consumer goods sector. The same results were observed in the results of a study by Sudiyatno, Puspitasari, \& Kartika (2012) that examined Indonesian manufacturing companies. In line with them, Mursalim et al. (2015) shows a positive influence of profitability on firm value. From the explanation above, it can be concluded that financial performance has a positive effect on firm value.

$\mathbf{H}_{7}$ : Financial performance has a positive effect on firm value.

\section{RESEARCH METHODOLOGY}

The study population for this research were 41 companies from the consumer goods industry sector and a sample of 28 companies determined through the purposive sampling method. The sample selection criteria are the consumer goods sub-sector companies listed on the Indonesian Stock Exchange before 2010. The financial report data used is the financial report data from 2010-2017. The indicator to measure asset structure is fixed asset to total assets. An 
indicator to measure capital structure using a debt to equity ratio. Financial performance uses the indicator return on investment, while the firm value uses the price to book value indicator (Ross, 2002).

The data collected were processed using path analysis technique. Structural equations that can be formed from this research are as follows:

1. Company performance $=b_{1}$ asset structure $+b_{2}$ capital structure $+e_{1}$

2. Firm value $\quad=b_{1}$ asset structure $+b_{2}$ capital structure $+b_{3}$ company performance

$$
+\mathrm{e}_{2}
$$

3. Company performance $=b_{1}$ asset structure $+e_{3}$

4. Firm value $\quad=b_{1}$ asset structure $+b_{2}$ capital structure $+e_{4}$

5. Financial performance $=b_{1}$ capital structure $+e_{5}$

6. Firm value $\quad=b_{1}$ capital structure $+b_{2}$ financial performance $+e_{6}$

The results gotten from the path analysis were tested using the SOBEL test. According to (Ghozali, 2016):

$$
\mathrm{Sp} 2 \mathrm{p} 3=\sqrt{\mathrm{p} 3^{2} \mathrm{Sp} 2^{2}+\mathrm{p} 2^{2} \mathrm{Sp} 3^{2}+\mathrm{Sp} 2^{2} \mathrm{Sp} 3^{2}}
$$

Based on the results of this Sp2p3, the $t$ value of the mediation effect statistic can be calculated with the following formula:

$$
\mathrm{t}=\frac{\mathrm{p} 2 \mathrm{p} 3}{\mathrm{Sp} 2 \mathrm{p} 3}
$$

If the $\mathrm{t}_{\text {count }}$ value is greater than $\mathrm{t}$ table then the intervening variable can mediate the influence between the independent variables on the dependent variable. The $t$ table value is based on the general provisions of 1.96 .

\begin{tabular}{|c|c|c|c|c|c|}
\hline Model & B & $\mathbf{T}$ & $\mathbf{F}$ & $\mathbf{R}$ & Adj.R $\mathbf{R}^{2}$ \\
\hline \multicolumn{6}{|c|}{ Equation 1} \\
\hline Constant & $-0,233$ & $-1,491$ & \multirow{3}{*}{$14,466 * *$} & \multirow{3}{*}{0.354} & \multirow{3}{*}{0.117} \\
\hline FATA $\left(X_{1}\right)$ & 0.608 & $4,650 * *$ & & & \\
\hline $\operatorname{DER}\left(\mathrm{X}_{2}\right)$ & 0.170 & 0.357 & & & \\
\hline \multicolumn{6}{|c|}{$\mathrm{a}=$ dependent variable: $\mathrm{ROI}$} \\
\hline \multicolumn{6}{|c|}{ Equation 2} \\
\hline Constant & 730,599 & $4,039 * *$ & \multirow{5}{*}{$3,820 *$} & \multirow{5}{*}{0.232} & \multirow{4}{*}{0.040} \\
\hline FATA $(\mathrm{X} 1)$ & $-1402,051$ & $-2,58 *$ & & & \\
\hline DER (X2) & $-151,002$ & $-0,954$ & & & \\
\hline ROI (Z) & 75,085 & $-0,927$ & & & \\
\hline \multicolumn{4}{|c|}{$\mathrm{a}=$ dependent variable: $\mathrm{PBV}$} & & \\
\hline \multicolumn{6}{|c|}{ Equation 3} \\
\hline Constant & $-0,069$ & $-0,429$ & $6,639 *$ & 0.178 & 0.027 \\
\hline
\end{tabular}

\section{DISCUSSION}

Table 1. Consumer Goods Industry Sector Company Hopotesis testing 


\begin{tabular}{|c|c|c|c|c|c|}
\hline FATA (X1) & 1,153 & $2,577 *$ & & & \\
\hline $\mathrm{a}=$ dependent $\mathrm{ROI}$ variable & & & & & \\
\hline \multicolumn{6}{|c|}{ Equation 4} \\
\hline Constant & 688,085 & $3,926 * *$ & \multirow[b]{2}{*}{$5,278 * *$} & \multirow[b]{2}{*}{0.223} & \multirow[b]{2}{*}{0.040} \\
\hline FATA (X1) & $-1618,437$ & $-3,248 * *$ & & & \\
\hline ROI (Z) & 51,071 & 0.664 & & & \\
\hline \multicolumn{6}{|l|}{$\mathrm{a}=$ dependent variable $\mathrm{PBV}$} \\
\hline \multicolumn{6}{|c|}{ Equation 5} \\
\hline Constant & $-0,195$ & $-1,722 *$ & \multirow[t]{2}{*}{$28,928 * *$} & \multirow[t]{2}{*}{0.353} & \multirow[t]{2}{*}{0.12} \\
\hline DER (X2) & 0.629 & $5,379 * *$ & & & \\
\hline \multicolumn{6}{|l|}{$\mathrm{a}=$ dependent variable ROI } \\
\hline \multicolumn{6}{|c|}{ Equation 6} \\
\hline Constant & 412,079 & $3,096 * *$ & \multirow{3}{*}{$2,387 *$} & \multirow{3}{*}{0.152} & \multirow{3}{*}{0.013} \\
\hline DER (X2) & $-318,908$ & $-2,183 *$ & & & \\
\hline ROI (Z) & 69,873 & 0.852 & & & \\
\hline \multicolumn{6}{|c|}{$\begin{array}{l}\mathrm{a}=\text { dependent vaiable PBV } \\
\text { Source: data processed by SPSS 22. } 2018 \\
\text { Information: } \\
*=5 \% \text { significance level } \\
* *=1 \% \text { significance level }\end{array}$} \\
\hline
\end{tabular}

The results of hypothesis tested in the study can be seen in Table 1 . The asset structure in equations one and three has positive effect on financial performance. The value of $t$ counts are 4.65 and 2.577. Beta coefficients of 0.608 and 1.153. In equation one, the level of significance of the effect of asset structure on financial performance is less than one percent. Whereas in equation three, the effect of asset structure on financial performance is less than five percent of the significance level. The positive influence of asset structure on the financial performance of the consumer goods industry sector is due to the low investment in fixed assets in the sector over the last eight years which is an average of only $32.26 \%$. This low average fixed asset investment shows that companies can still add fixed assets to support increment in production which in turn can increase revenue.

The large population and stable economic growth of Indonesia makes it a potential market for the expansion of production facilities in consumer goods industry. In the equations two and four, asset structure has a negative effect on firm value where $t$ arithmetic is -2.58 and 3.248 with beta -1402.051 and $-1618,437$ respectively. In equation two, the level of significance of the effect of the asset structure on the firm value is less than five percent while in equation four the significance level is less than one percent. The negative influence of this asset structure shows that if the consumer goods sector industry adds fixed assets, the market responds negatively. It can be explained that for the last eight years, the average fixed assets owned by the company in this sector amounts to $32.26 \%$ and at an average ROI of $27.57 \%$. But, the average PBV was 165,387. It happens because there are companies that have very high PBVs reaching an average of 6973 times. From the amount of data processed there are 12\% of data having PBV above 50 times. This shows that there are several companies in this sector that have been overvalued. In addition, this sector has several companies engaged in the food and daily goods industry with low operating margin, but has a tight level of competition. This sector incorporates 
several cigarette industries whose prospects are not so good in the future, because of government's policies.

The capital structure in the first equation has no effect on financial performance where $t$ arithmetic is 0.357 while beta is 0.17 . In equation five, capital structures have positive effect on company performance with $t$ counts of 5.379 , beta of 0.629 , and the level of significance affecting less than one percent. In equation two, capital structure does not affect the firm value where $t$ arithmetic is -0.995 and beta -151.002 . This happens because of $35 \%$ of the company's data which has a capital structure below $50 \%$ over the past eight years and a debt ratio of less than $20 \%$. The average financial performance as measured by ROI is around $27.58 \%$. It means that the debt ratio is still relatively low and companies that expand their fixed assets with debt funding sources are able to improve their financial performance.

In equation six, capital structures have negative effects on the firm value with $t$ arithmetic of -2.183 and beta -318.908 . The level of significance of the influence of capital structure on the firm value is less than five percent. The negative influence of capital structure towards firm value is caused by several companies in this sector. They have debt ratios above 100 percent but have financial performance that is below average while the PBV is above 10 times. This condition shows that the companies do not have good financial performance but they are overvalued. The company's performance in equations two, four, and six has no effect on firm value where $t$ counts are $-0.927,0.664$, and 0.852 , beta $75.085,51.071$, and 69.873 . This happens because of the fact that some companies in this sector have low company performance but have a high PBV value. Some even have a value of 50 times. There are several companies that have good performance but have a low PBV. Some even have less than one.

Table 2. Results of Variable Influences

\begin{tabular}{|c|c|c|c|c|}
\hline Variable Influence & Direct & Indirect Influence & Total & Sobel \\
\hline \multicolumn{5}{|c|}{ Effect of Asset Structure on Firm value, Financial Performance as Mediation } \\
\hline $\mathrm{X}_{1} \rightarrow \mathrm{Y}$ & $-1618,437$ & $1,153 \times 51,071=58,885$ & $-1,559,55$ & \multirow{3}{*}{0.6018} \\
\hline$X_{1} \rightarrow Z$ & 1,153 & - & 1,153 & \\
\hline $\mathrm{Z} \rightarrow \mathrm{Y}$ & 51,071 & - & 51,071 & \\
\hline \multicolumn{5}{|c|}{ Effect of Asset Structure on Firm value, Financial Performance as Mediation } \\
\hline $\mathrm{X}_{2} \rightarrow \mathrm{Y}$ & $-318,908$ & $0.629 \times 69.873=43.95$ & $-274,958$ & \multirow{3}{*}{0.8185} \\
\hline $\mathrm{X}_{2} \rightarrow \mathrm{Z}$ & 0.629 & - & 0.629 & \\
\hline$Z \rightarrow Y$ & 69,873 & - & 69,873 & \\
\hline
\end{tabular}

In table 2 above, the first path analysis shows that the value of indirect influence (58.885) is greater than the value of direct influence (-1.618.437). It means that financial performance can mediate the effect of asset structure on the value of a company. To be sure, a SOBEL test was conducted. The results of a small test of 0.6018 test compared with $\mathrm{t}$ table value of 1.96 (five percent significance) shows a smaller test score. It means that financial performance cannot mediate the effect of asset structure on firm value. The second path analysis shows an indirect influence value of 43.95 , greater than the value of direct influence -318.908 . It means that financial performance can mediate the indirect influence of capital structure on firm value. 
Sobel test for the second equation of 0.8185 turns out to be smaller than the $t$ table value of 1.96 . It means that financial performance cannot mediate the influence of capital structure on financial performance.

\section{CONCLUSION}

The results of the data analysis show that the asset structure of the companies in the consumption sector of Indonesia has a positive influence on company performance and firm value. $\mathrm{H}_{1}, \mathrm{H}_{2}, \mathrm{H}_{3}$, and $\mathrm{H}_{4}$, shows fixed assets has a positif influence on company performance. This finding according to the research from Olatunji \& Adegbite (2014), Muritala (2012), and Mursalim et al. (2015). This happens because the average fixed asset investment that supports the company's operations in this sector is still quite low. But, the prospect of most companies in this sector is still very broad. It means that there are still opportunities for expansion in this sector. Capital structure has a positive effect on financial performance but does not affect the firm value. This finding according to the $\mathrm{H}_{5}$, and $\mathrm{H}_{6}$ It means that some companies in this sector are able to expand using sources of funds from debt. The company's performance in this sector does not affect the firm value and cannot mediate the influence of the asset structure and capital structure on the firm value. This finding contradicts the $\mathrm{H}_{2}$, and $\mathrm{H}_{6}$, because test result for $\mathrm{H}_{2}$ show $\mathrm{t}$ score is $-0,954$, and test result for $\mathrm{H}_{6}$, show $\mathrm{t}$ score 0,852 . This result is contrary to the researchs conducted by Boroujeni et al. (2013), Chaganti \& Damanpour (1991), and Mursalim et al. (2015) who find that capital structure has positive effect on profitability and firm value.

\section{LIMITATIONS}

The limitations of the study can be seen in the fact that very limited indicators where used in this study with each variable using only one measurement indicator. In addition, the indicators available for each variable are very diverse as well as the grouping of companies. This can be seen from the fact that there are various types of consumer goods industries such as pharmaceutical companies, companies that produce products for beauty care, household needs, food industry (snacks), and the cigarette industry where each company has different characteristics. These characteristics may affect the assets as well as performance of these companies.

\section{REFERENCES}

Bhullar, P. S. (2017). Empirical Analysis of Operating Efficiency and Firm Value: A Study of Fast Moving Consumer Goods and Pharmaceutical Sector in India. International Journal of Economics and Financial Issues, 7(3), 671-675. Retrieved from https://www.econjournals.com/index.php/ijefi/article/view/4400.

Boroujeni, H. N., Noroozi, M., Nadem, M., \& Chadegani, A. A. (2013). The Impact of Capital Structure and Ownership Structure on Firm Performance: A Case Study of Iranian Companies. Research Journal of Applied Sciences, Engineering and Technology, 6(22), 4265-4270. https://doi.org/10.19026/rjaset.6.3543.

Brigham, E. F., \& Gapenski, L. C. (1997). Financial Management: Theory and Practice (Eight Edit). The Dryden Press, Harcourt Brace College Publishers. 
Brigham, E. F., \& Houston, J. F. (2006). Fundamentals of Financial Management= Dasar-Dasar Manajemen Keuangan, Buku 1. Alih Bahasa, Ali Akbar Yulianto (10th ed.). Jakarta: Salemba Empat.

Chaganti, R., \& Damanpour, F. (1991). Institutional Ownership, Capital Structure, and Firm Performance. Strategic Management Journal, 12(7).

Chen, K. (2002). The Influence of Capital Structure on Company Value with Different Growth Opportunities. EFMA 2002 London Meetings.

Djaja, I. (2017). All About Corporate Valuation, Memetakan, Menciptakan, Mengukur, dan Merealisasikan Nilai Perusahaan. Jakarta: PT Elex Media Komputindo.

Ghozali, I. (2016). Aplikasi Analisis Multivariate dengan Program IBM SPSS 23 (8th ed.). Semarang: Badan Penerbit Fakultas Ekonomi Universitas Diponegoro.

Harjito, A., \& Martono. (2013). Manajemen Keuangan (Editi Ke-2). Yogyakarta: Ekonisia, Kampus Fakultas Ekonomi, Universitas Islam Indonesia.

Martono, \& Harjito, A. (2003). Manajemen Keuangan, Teori dan Aplikasi. Jakarta: Erlangga.

Muritala, T. A. (2012). An Empirical Analysis of Capital Structure on Firms' Performance in Nigeria Taiwo. International Journal of Advances in Management and Economics, 1(5), 116-124.

Mursalim, Hendragunawan, Alamzah, N., \& Sanusi, A. (2015). Financial Decision, Innovation, Profitability and Company Value: Study on Manufacturing Company Listed in Indonesian Stock Exchange. Information Management and Business Review, 7(2), 72-78.

Myers, S. C. (2001). Capital Structure. Journal of Economic Perspectives, 15(2), 81-102.

Olatunji, T. E., \& Adegbite, T. A. (2014). Investment in Fixed Assets and Firm Profitability: Empirical Evidence from the Nigerian Banking Sector. Asian Journal of Social Sciences and Management Studies, 1(3), 78-82. Retrieved from http://www.asianonlinejournals.com/index.php/AJSSMS.

Prasad, D., Bruton, G. D., \& Merikas, A. G. (1997). Long-Run Strategic Capital Structure. Journal of Financial and Strategic Decisions, 10(1), 47-58.

Riyanto, B. (2013). Dasar-Dasar Pembelanjaan Perusahaan (Edisi 4, C). Yogyakarta: BPFE UGM.

Ross, S. A. (2002). Fundamentals Of Corporate Finance (Sixth Edit). McGraw-Hill Irwin.

Ross, S. A., Westerfield, R. W., Jaffe, J. F., \& Jordan, B. D. (2015). Corporate Finance: Core Principles And Applications (Fourth Edi). New York: McGraw-Hill Education.

Salim, M., \& Yadav, R. (2012). Capital Structure and Firm Performance: Evidence from Malaysian Listed Companies. Procedia - Social and Behavioral Sciences, 65, 156-166. https://doi.org/10.1016/j.sbspro.2012.11.105.

Sartono, A. (2000). Manajemen Keuangan (E. 3, ed.). Yogyakarta: BPFE.

Sudiyatno, B., Puspitasari, E., \& Kartika, A. (2012). The Company's Policy, Firm Performance, and Firm Value: An Empirical Research on Indonesia Stock Exchange. American International Journal of Contemporary Research, 2(12), 30-40.

Vătavu, S. (2015). The Impact of Capital Structure on Financial Performance in Romanian Listed Companies. Procedia Economics and Finance, 32(15), 1314-1322. https://doi.org/10.1016/s2212-5671(15)01508-7. 